\title{
Management of Strawberry Anthracnose Using Plant Essential Oils as Bio-fungicides, and Evaluation of Their Effects on Quality of Strawberry Fruit
}

\author{
Somaieh Hosseni ${ }^{1}$, Jahanshir Amini ${ }^{1}{ }^{*}$, Javad Nazemi Rafei ${ }^{1}$, and Jalal Khorshidii ${ }^{2}$ \\ ${ }^{1}$ Department of Plant Protection, College of Agriculture, University of Kurdistan, Sanandaj, IRAN \\ ${ }^{2}$ Department of Horticultural Science, University of Kurdistan, Sanandaj, IRAN
}

\begin{abstract}
Colletotrichum nymphaeae is the causal agent of strawberry anthracnose, which is one of the most important disease affecting strawberry plant in Iran. This research aimed to apply the selected plant essential oils (EOs) such as Achillea millefolium, Mentha longifolia, and Ferula kuma to the management of strawberry anthracnose disease under in vitro, in vivo, and greenhouse conditions. In vitro tests indicated that all the EOs and fungicide were able to inhibit mycelial growth and conidial germination of the pathogen. Scanning electron microscopy (SEM) revealed that EOs significantly suppressed the mycelia growth and caused a change in morphology of fungal mycelia. The severity of strawberry anthracnose disease was significantly $(p \leq 0.05)$ reduced by all EOs under in vivo and greenhouse conditions. Results of all experiments showed that $M$. longifolia EO was the best EO to control $C$. nymphaeae. Also, EOs almost reduced weight loss and preserved firmness, ascorbic acid, total phenol, antioxidant activity (DPPH), and enzyme peroxidase activity in treated fruit. Moreover, EOs preserved the sensory quality of strawberry fruit during the storage period so that there were no significant differences between treatments (EOs) in their appearance, flavor, odor attributes, and overall evaluation compared to the control. Our results indicate that EOs are excellent bio-fungicides for the management of strawberry anthracnose.
\end{abstract}

Key words: Captan, Colletotrichum nymphaeae, DPPH, sensory quality

\section{Introduction}

Kurdistan Provence (west of Iran) is the most important habitat of strawberry (Fragaria $\times$ ananassa Duch.) in Iran. Strawberry anthracnose disease, caused by Colletotrichum nymphaeae, is one of the main pre-harvest and post-harvest diseases that affect strawberry production in Iran. Several species of Colletotrichum such as C. acutatum J.H Simmonds, C. fragariae Brooks, C. gloeosporioides (Penz), and C. nymphaeae (Pass.) cause strawberry anthracnose disease ${ }^{1)}$. C. nymphaeae is one of the important pathogens causing strawberry anthracnose diseases in Kurdistan province, Iran. This widespread, aggressive species $^{2}$ is a limiting factor in strawberry production. The symptoms appear on the aerial parts of the strawberry plant(i.e., stolon, petiole, flower, fruit, leaf, and crown), especially fruit decay such as sunken lesions and conidial ooze on fruits ${ }^{1}$. Resistance cultivar to this fungus has not been found and reported in Iran yet. Application of chemical fungicides on fruit against the disease is limited and harmful for human health. Also, public demand to reduce fungicides use and the development of fungicide resistant has increased the need for alternative control strategies. In this regard, applications of fungicides are not permitted as postharvest treatments under organic production rules ${ }^{3)}$. Therefore, an alternative to fungicides is needed for managing the strawberry anthracnose. Physical, chemical and biological methods have been evaluated in the management of strawberry fruit production ${ }^{4}$. The use of plant essential oils (EOs) is a promising alternative to chemical products and has the potential for postharvest diseases management $^{5)}$. The plant EOs have antimicrobial activities and induce the host defenses system ${ }^{6}$. Several plant EOs have been evaluated and reported as effective management of postharvest disease on citrus $^{5,7)}$, pepper $^{8)}$, avocados ${ }^{9)}$, gray mold of table grapes ${ }^{10)}$ and banana ${ }^{11)}$. Application of plant EOs allows controlling the plant diseases and preserving the fruits during postharvest ${ }^{12)}$. Moreover, they do not pose any risk to human health and rather improve the fruit

\footnotetext{
*Correspondence to: Jahanshir Amini, Department of Plant Protection, College of Agriculture, University of Kurdistan, Sanandaj, IRAN

E-mail: jamini@uok.ac.ir

Accepted January 21, 2020 (received for review May 4, 2019)
}

Journal of Oleo Science ISSN 1345-8957 print / ISSN 1347-3352 online

http://www.jstage.jst.go.jp/browse/jos/ http://mc.manusriptcentral.com/jjocs 
quality $^{11,13)}$.

The potential of EOs to control strawberry anthracnose by Achillea millefolium, Ferula kuma, and Mentha longifolia has not been reported yet. The objective of this research is to evaluate the potential of EOs of these plants to control the strawberry anthracnose under in vitro, in vivo, and greenhouse conditions. Also, the effect of EOs on quality of strawberry fruit after harvest is evaluated.

\section{Experimental Procedures}

\subsection{Fungal pathogen and inoculum preparation}

C. nymphaeae isolate CCh32 (GenBank Acc. No. CCTUCCh32) causing anthracnose strawberry used in this research was obtained from the culture collection of the Plant Protection Department of University of Tabriz in Iran ${ }^{1)}$. The isolate was previously isolated from infected strawberry plants in Kurdistan Province. The pathogen was cultured on Potato dextrose agar(PDA) for 10 days at $25 \pm$ $2^{\circ} \mathrm{C}$ and was kept on PDA at $4^{\circ} \mathrm{C}$. The conidia of the pathogen were collected from 14-days-old cultures by filtration and were rinsed with sterile water. Next, the concentration of conidial suspension was adjusted to $1 \times 10^{6} \mathrm{CFU} / \mathrm{mL}$ using a hemocytometer.

\subsection{Plant and fruits}

The healthy strawberry plants cv. Paros (5-weeks old) were used in experiments. Plants were grown in greenhouse conditions at 24 to $27^{\circ} \mathrm{C}, 60-70 \%$ relative humidity, $16 \mathrm{~h}$ light, and $8 \mathrm{~h}$ darkness. Healthy strawberry fruits (c.v. Paros) of uniform size shape, maturity and free from any indication of mechanical injury and pathogenic infection were collected for the experiments. The fruits were transferred to the laboratory on June 2016, washed with distilled water, and air-dried by sterile paper under the laminar hood for $15 \mathrm{~min}$.

\subsection{Essential oil extraction}

The specimens of Achillea millefolium, Ferula kuma and Mentha longifolia were collected from the growing field in their natural habit (Marivan and Ghorveh, Kurdistan Province, Iran) at the flowering stage on June 2016. The plant specimens were shade dried. The dried plant materials $(300 \mathrm{~g})$ were selected and extraction of EOs was carried out through Clevenger-type apparatus and hydrodistilled for $5 \mathrm{~h}^{14)}$. The extracted essentials oil was dried in anhydrous sodium sulfate $\left(\mathrm{Na}_{2} \mathrm{SO}_{4}\right)$. Then, the oils were preserved in a sealed amber bottle at $4^{\circ} \mathrm{C}$ in the refrigerator until use.

\subsection{GC-MS analysis}

The chemical analysis of EOs were performed on an Agilent 7890A gas chromatography (GC) coupled with
Agilent 5975C mass spectrometry(MS) (Agilent Technologies, USA), using a HP-5 MS capillary column (30 m length $\times 0.25 \mathrm{~mm}$ internal diameter, film thickness $0.25 \mu \mathrm{m}$ ) on July 2016 and their constituents were measured ${ }^{15)}$. GC oven temperature was kept at $50^{\circ} \mathrm{C}$ for 5 min and programed to $240^{\circ} \mathrm{C}$ with a rate of $3^{\circ} \mathrm{C} / \mathrm{min}$. The volume of sample injection was $1 \mu \mathrm{L}$ and helium was used as the carrier gas with a flow rate of $0.8 \mathrm{~mL} / \mathrm{min}$. Injection and detector temperature were set as of 290 and $250^{\circ} \mathrm{C}$, respectively. The mass spectrometer parameters were recorded at electron energy of $70 \mathrm{eV}^{15)}$. The components of EOs were identified by their inhibition index and compared with those reported in the literature and of their mass spectra with those in the WILEY/ NBS ${ }^{16,17}$.

\subsection{Antifungal activity of EOs on mycelial growth}

Antifungal activity of EOs on mycelial growth was calculated using contact and vapor methods on July $2016^{18)}$. In the contact method, the antifungal assay of EOs and commercial fungicide of Captan ( $50 \%$ a.i. WP) were carried out in the plates (9-cm-diameter) containing a PDA medium. Each concentration of EOs and fungicide was dissolved in Tween $^{\circledR} 80$ (0.05\% v/v) (Merck, Darmstadt, Germany). The solution was added to autoclaved PDA media at $40^{\circ} \mathrm{C}$ at plates (9-cm-diameter). Six different concentrations of EOs and fungicide were selected by pre-test for the pathogen (Fig. 1). In order to evaluate the antifungal ability of EOs and fungicide, a disc of 5-mm in diameter (7-days old stock cultures) of the pathogen was prepared by cork borer and placed in the center of the plates. Plates containing PDA medium, Tween ${ }^{\circledR} 80$ and pathogen were used as control. Three replicates per each treatment were used. All plates were incubated at $25 \pm 2^{\circ} \mathrm{C}$ for 10 days. The diameter of fungal colonies of $C$. nymphaeae was measured (mm) and the inhibition percentage was calculated using the following formula: inhibition percentage $=[$ (control - treatment $) /$ control $] \times 100$. Next, the median effective inhibitory concentration $\left(\mathrm{EC}_{50}\right)$ was measured for EOs and fungicide $(\mu \mathrm{L} /$ $\mathrm{L}$ ) on C. nymphaeae. The Probit analysis was used to evaluate $\mathrm{EC}_{50}$ with the SPSS software versions 16.0.

In the vapor method, the effect of the volatile phase of EOs and Captan fungicide was investigated using a filter paper (6-mm-diameter) in plates (9-cm-diameter). First, one mycelial disc plug of the pathogen (5-mm-diameter) was taken from the margin of a 7-day-old culture and was placed in the center of plates containing PDA medium. Then, the filter paper was dipped in different concentration of the EOs as well as Captan and placed in the inner space of the inverted lid of the plates. Afterward, the plates were immediately sealed with parafilm to prevent any loss of the volatile compounds. In the next step, the plates were incubated at $25 \pm 2^{\circ} \mathrm{C}$ for 10 days. Then, radial mycelial growth was measured and the inhibition percentage was measured using the formula mentioned above. 


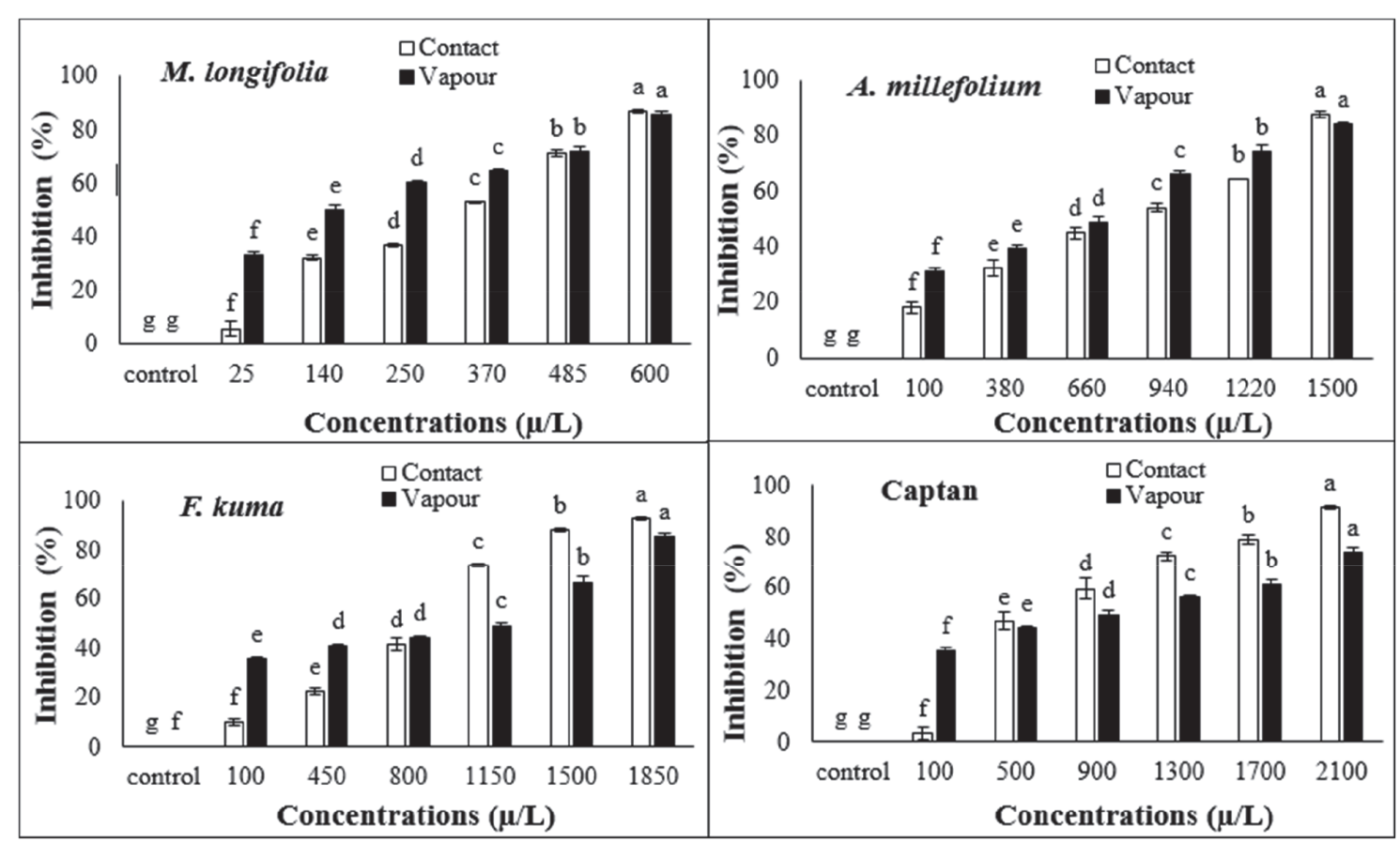

Fig. 1 Antifungal activity of EOs on mycelial growth of $C$. nymphaeae after 10 days using two contact and vapor methods. Data with different letters indicate significantly different $(p \leq 0.05)$ according to statistics analysis using SAS software version 8.2 with Duncan multiple-ranges test (DMRT).

\subsection{Antifungal activity of EOs on conidial germination}

Effect of EOs of Achillea millefolium, Mentha longifolia, and Ferula kuma at concentrations 1500, 600, and $1850 \mu \mathrm{L} / \mathrm{L}$ respectively and fungicide at the concentration of $2100 \mu \mathrm{L} / \mathrm{L}$, were evaluated on conidial germination of the pathogen using two contact and vapor methods on PDA plates on July 2016. In the contact method, one $\mathrm{mL}$ of different concentrations of EOs and fungicide $(\mu \mathrm{L} / \mathrm{L})$ supplemented by $0.05 \%$ of Tween ${ }^{\circledR} 80(0.05 \%$ v/v) (Merck, Darmstadt, Germany)were pipetted into micro tube (5-mLvolume). Then, one $\mathrm{mL}$ of the suspension of the pathogen $\left(10^{6}\right.$ conidia/mL) was added to it and was placed on the shaker in $120 \mathrm{rpm}$ at $25 \pm 2^{\circ} \mathrm{C}$ for $24 \mathrm{~h}$. Afterward, $50 \mu \mathrm{L}$ of resulting solutions were pipetted on water agar medium (WA) in plates (9-cm-diameter) and distributed evenly with a spreader. In the next step, $50 \mu \mathrm{L}$ of a conidial suspension of the pathogen $\left(10^{6}\right.$ conidia/mL $)$ alone supplemented by $0.05 \%$ of Tween ${ }^{\circledR} 80(0.05 \%$ v/v) (Merck, Darmstadt, Germany)was added to WA medium as a control treatment. Three replicates per each treatment were prepared. Plates were incubated at $25 \pm 2^{\circ} \mathrm{C}$ for $48 \mathrm{~h}$ under a 12 -h photoperiod. Then, 200 conidia from each replicate were evaluated to assess the percentage of conidial germination (out of the total number of evaluated spores) using an optical microscope $(40 \times$ magnification $)$. A conidium was adverted to have germinated if the length of the germ tube was larger than or equal to the conidial diameter. The percentage of inhibition of conidial germination of $C$. nymphaeae by EOs and fungicide was calculated and compared to control with the above-mentioned formula ${ }^{19)}$.

In the vapor method, following the above method, $10 \mathrm{~mL}$ of WA medium was added to each plate (9-cm-diameter). A total of $50 \mu \mathrm{L}$ of suspension of the pathogen $\left(10^{6}\right.$ conidia/ $\mathrm{mL}$ ) was spread onto WA medium in plates. Then, sterile filter paper disc (5-mm-diameter) was dipped into one $\mathrm{mL}$ of each concentration of EO and fungicide for one min, was placed in the inner space of the inverted lid of the plates. The plates containing spore solution of the pathogen were placed upside the EOs containing plates. Plates containing filter paper discs dipped in sterile water were used as the control. Then, plates were sealed with parafilm, incubated at $25 \pm 2{ }^{\circ} \mathrm{C}$ for $48 \mathrm{~h}$ and tried similarity discussed previously. The inhibition percentage was evaluated with the abovementioned formula ${ }^{20)}$.

\subsection{Morphological changes in presence of dill EOs}

Mycelia of the pathogen were treated with EOs of Achillea millefolium, Ferula kuma, and Mentha longifolia at concentration of 1500, 1850 and $600 \mu \mathrm{L} / \mathrm{L}$, respectively, based on contact phase for 7 days. Then, the mycelia of $C$. nymphaeae was freeze-dried. Morphological changes of mycelia were observed using scanning electron microscope (SEM) on August 2016. 


\subsection{Antifungal activity tests in vivo and greenhouse con- ditions}

Effect of EOs and fungicide on fruit decay development and strawberry anthracnose was evaluated in vivo and greenhouse conditions, respectively on September 2017. The concentrations of EOs of Achillea millefolium (1500 $\mu \mathrm{L} / \mathrm{L})$, Ferula kuma $(1850 \mu \mathrm{L} / \mathrm{L})$, Mentha longifolia $(600$ $\mu \mathrm{L} / \mathrm{L})$, and Captan $(2100 \mu \mathrm{L} / \mathrm{L})$ were selected based on total inhibitory effects in vitro.

\subsection{Fruit decay test}

To evaluate the antifungal efficacy of the volatile fraction of the EOs on fruit decay development, healthy strawberry fruits were surface sterilized by dipping in $70 \%$ ethanol for $3 \mathrm{~s}$, rinsed in sterile distilled water (three times), and dried by sterile paper under a laminar hood for $10 \mathrm{~min}$. After that, $20 \mu \mathrm{L}$ conidial suspensions of C. nymphaeae $\left(10^{6}\right.$ conidia/mL) amended with Tween ${ }^{\circledR} 80$ (0.05\% v/v) (Merck, Darmstadt, Germany) were pipetted onto the fruit surface. The fruits inoculated with distilled water with Tween ${ }^{\circledR} 80$ $(0.05 \%, v / v)$ and fungal spore were used as the negative and positive control, respectively. Inoculated fruits were put in plastic boxes, followed by adding $2 \mathrm{~mL}$ of different concentrations of EOs and fungicide of Captan to the dish (2 $\mathrm{cm}$ diameter and $1.5 \mathrm{~cm}$ high) and placing it in the center and at the bottom of each plastic box. A total of 20 healthy fruits were selected for each treatment and distributed in four boxes. In the control treatment, plastic boxes were put distilled water. All plastic boxes were immediately sealed with layers of parafilm to avoid any loss of volatile compounds and incubated at $25 \pm 2{ }^{\circ} \mathrm{C}$ under a regime of 12 $\mathrm{h}$ of light and $12 \mathrm{~h}$ of darkness for 7 days. After one week, the fruit decay development (disease severity) was measured.

\subsection{Greenhouse studies}

To determine the inhibition effect of EOs in greenhouse condition, the strawberry plants cv. Paros (five weeks old) were used. The strawberry plants were sprayed with selected concentrations of EOs amended by Tween ${ }^{\circledR} 80$ (0.05\% v/v) (Merck, Darmstadt, Germany) until all plant was wetted to run-off using a hand-held atomizer. The plants were individually covered with a 0.1 -mm-thick transparent plastic film to maintain moisture and incubated at $24-27^{\circ} \mathrm{C}, 60-70 \% \mathrm{RH}$ for $24 \mathrm{~h}$ in the dark. After that, 5 $\mathrm{mL}$ of the pathogen inoculums at a concentration of $1 \times 10^{6}$ conidia/mL were sprayed onto each plant with a hand-held atomizer. The plants were sprayed with distilled water and fungal spore, which were utilized as the negative and positive control, respectively. The plants were incubated in plastic bags for $48 \mathrm{~h}$ in the dark as before to stimulate infection $^{21,22)}$. Then, plants were incubated for 60 days in greenhouse conditions at 24 to $27^{\circ} \mathrm{C}, 60-70 \%$ relative humidity, $16 \mathrm{~h}$ light, $8 \mathrm{~h}$ darkness. After 2 months, the disease severity was measured.

\subsection{Disease severity}

Disease severity on strawberry fruits was scored after seven days using a scale of 0 to 5 through the method described by ${ }^{23)}$ with some modification. A rating of 0 was scored when there was no symptom of anthracnose disease on the surface of the fruits (healthy fruit). The rates of 1,2 , 3,4 and 5 were scored when $<20,20.1$ to $40,40.1$ to 60 , 60.1 to 80 , and 80.1 to $100 \%$ of the fruit surface showed anthracnose symptom, respectively.

Disease severity in greenhouse conditions after 2 months was scored on petioles of strawberry plants by the method described $b^{24)}$ using a scale of 0 to 5 . A rating of 0 was scored when there was no symptom of lesions on petiole (healthy petiole or without lesions). Ratings of 1, 2, 3, and 4 were scored when $<3 \mathrm{~mm}, 3$ to $10 \mathrm{~mm}, 10.1$ to $20 \mathrm{~mm}$ and $>20 \mathrm{~mm}$ of the petiole showed lesions symptom, respectively. If lesions entirely appeared on petiole and the plant is dead, a rating of 5 was scored. Finally, efficacy percent was measured using the following formulas:

Efficacy $\%=[($ disease index of control $)-($ disease index of treated) $] /$ disease index of control $\times 100$.

\subsection{Effect of EOs on fruit quality}

Healthy and mature strawberry fruits of similar size and color (70\% red stage of ripening) were harvested from a local farm on October 2016 and immediately (within $1 \mathrm{~h}$ ) transported to the laboratory and incubated at $1^{\circ} \mathrm{C}$. At first, the fruits were rinsed in sterile distilled water and were dried under a laminar hood for $15 \mathrm{~min}$. They were sprayed separately with EOs of Achillea millefolium, Ferula kuma, and Mentha longifolia at concentrations $(\mu \mathrm{L} / \mathrm{L})$ of 1500,1850 , and 600, respectively, and sterile distilled water as the control. The inoculated fruits were dried at $25^{\circ} \mathrm{C}$ for one hour and then the fruits were placed into polyethylene bags and incubated in cold storage $\left(1^{\circ} \mathrm{C}\right.$ and $75 \% \mathrm{RH})$ for 10 days. Six fruits per replicate and three replicates per treatments were used. The storage quality parameters of the treated strawberry fruit were recorded as described below. It was indexed before storage(i.e., harvesting time) and eight days after the storage. All tests were performed duplicate. At last, treatments (with different combinations of factor levels) were analyzed in a factorial experiment with three replications in the frame of a Completely Randomized Design (CRD). Means of treatments were compared using Duncan's multiple range test. 2.12.1 Weight loss

The weight loss percentage of the treated strawberry fruits were recorded using the formula [(M1-M2)/M1] $\times$ 100 , where M1 denotes the weight of the strawberry fruit before storage and M2 is the final weight (after storage).

2.12.2 Fruit firmness

Fruit firmness was calculated using a TA.XT2i texture 
analyzer (Santam, STM-1, Iran) by performing a penetration test with an 5-mm diameter cylindrical probe. The speed of the prope was $3.0 \mathrm{~mm} / \mathrm{min}$ and a distance of $10 \mathrm{~mm}$ was used. The fruit firmness was recorded at two locations in the middle of the strawberry fruit. Finally, firmness was expressed as the maximum penetration force $(\mathrm{N})$.

\subsubsection{Ascorbic acid}

Ascorbic acid (vitamin C) was recorded described by Kevers et $a l^{25)}$. The results were expressed as mg ascorbic acid per $100 \mathrm{~g}$ of fruit fresh weight (FFW) basis.

2.12.4 Total phenol content

The total phenol content (TPC) of fruit juice was measured based on the Folin- Ciocalteu total phenolic assay ${ }^{26)}$. For this work, $20 \mu \mathrm{L}$ fruit extracts were dissolved in $250 \mu \mathrm{L}$ distilled water, $750 \mu \mathrm{L}$ solution of $10 \%$ Folin-Ciocalteau (v/ v) and $800 \mu \mathrm{L} 7.5 \% \mathrm{Na}_{2} \mathrm{CO}_{3}(\mathrm{w} / \mathrm{v})$. Samples were placed at room temperature in the dark for $60 \mathrm{~min}$ at $25^{\circ} \mathrm{C}$. Then, the absorption was measured at $765 \mathrm{~nm}$ by a spectrophotometer. The results were expressed as mg gallic acid per $100 \mathrm{~g}$ fruit fresh weight (FFW) basis.

2.12.5 Antioxidant activity

The antioxidant activity was measured according to the 2,2-diphenyl-1-picrylhdrazyl (DPPH) scavenging capacity method described by Patras et al. ${ }^{27)}$. For antioxidant activity assay, $200 \mu \mathrm{L}$ of fruit sample extracts were added to 500 $\mu \mathrm{L} \mathrm{DPPH}(0.238 \mathrm{mg}$ per one ml methanol). The resulting reaction mixture was kept at room temperature for $30 \mathrm{~min}$ at $25^{\circ} \mathrm{C}$. The absorbance was recorded at $515 \mathrm{~nm}$. The inhibition percentage of DPPH was measured as follows: DPPH Inhibition $\%=\left[\left(A_{b}-A_{s}\right) / A_{b}\right) \times 100$, where $A_{b}$ is the absorption in DPPH control and $\mathrm{A}_{\mathrm{s}}$ is absorption in treatment.

\subsubsection{Peroxidase(POD) activity}

The peroxidase (POD) activity was recoded according to the guaiacol method described by Ghanati et $a l^{28)}$, with slight modifications. The unit of enzyme activity was defined to be equivalent to a 0.01 per minute increase in the absorbance at $470 \mathrm{~nm}$ for two min. The result (enzyme activity) was expressed in U per gram fresh weight.

\subsection{Postharvest sensory quality analysis}

This research was performed on strawberry fruits without pathogen on October 2016. The generic descriptive analysis method was employed to determine whether there was any detectable difference in the flavors, odor, taste (sweet and sour), and appearance of fruit. Moreover, the overall assessment of the strawberry fruits exposed to the EOs vapors was compared to the control (inoculated to distilled water ${ }^{29}$. The strawberry fruits were removed from storage room 60 min prior to evaluation in order to equilibrate to room temperature. The sensory analyzes were performed in a sensor panel room of the Department of Plant protection in University of Kurdistan on three different days at 10:00 am at $24-26^{\circ} \mathrm{C}$. Sensory evaluation of the fruit inoculated by EOs was performed on the $10^{\text {th }}$ days of storage at $4^{\circ} \mathrm{C}$ by 11 assessors ( 5 males and 6 females within the age range of 20-30 years). There was a five min interval between testing and water was provided between assessors. All assessors were trained at the beginning of the experiment in order to become familiar with the experimental conditions. The qualitative score was performed on the basis of a 5 -point hedonic scale (1, very weak; 2 , weak; 3 , intermediate; 4 , good; and 5 , very good) for the sensory evaluation. Then, the data for sensory evaluation were tested for normality. Due to the lack of a normal distribution of the entire data, they were subjected to non-parametric analysis using the Kruskal-Wallis test in SPSS ver. 16.0.

\subsection{Statistical analysis}

Experiments were designed in a completely randomized design (CRD). Data were statistically analysed by standard analysis of variance (ANOVA) using the SAS software (Version 8.2; SAS Institute, Cary, NC, USA, 2013). Differences among different treatments were measured using Duncan's Multiple Range Tests (DMRT). All data were expressed as mean values \pm standard error $(\mathrm{SE})$. To measure $\mathrm{EC}_{50}$, Probit analysis was performed in the SPSS ver. 16.0. All experiments were performed in duplicate.

\section{Results and Discussion}

\subsection{Chemical composition of the EOs}

The chemical composition of the EOs of A. millefolium, F. kuma, and M. longifolia was analyzed by GC-MS (Tables 1,2 , and 3). In the present research, GC-MS analysis of $A$. millefolium EO identified 44 constituents, explaining more than $94.58 \%$ of total EOs. The major components of the A. millefolium EO were acetaldehyde,(3,3-dimethyl cyclohexylidene), (Z) - (20.152\%), eucalyptol(13.384\%), and 2-cyclohexen-1-ol, 4-ethyl-1,4-dimethyl-(5.715 \%). The main components of the F. kuma EO in the present study were bicyclo[2.2.1] heptan-2-ol,1,7,7-trimethyl-, acetate, (1S-endo)-(23.154\%), fenchyl acetate(18.993), $1 R$-alpha.-pinene (18.764\%), and camphene (13.915\%). The Bicyclo[3.1.1] hept-3-en-2-one, 4,6,6-trimethyl (43.412\%), cyclohexanone, 5-methyl-2-(1-methylethylidene)-(35.391\%), and eucalyptol(14.569\%) were identified as the major components of the M. longifolia EO by GC-MS analysis.

\subsection{Effect of EOs on Hyphal growth and conidial germi- nation}

All EOs significantly $(p \leq 0.05)$ reduced the mycelial growth (Fig. 1) and conidial germination (Table 4) of $C$. nymphaeae in vitro to compare the fungicide of Captan and control in contact and vapor phases. There were significant differences between their effects against $C$. nym- 
S. Hosseni, J. Amini, J. N. Rafei et al.

Table1 Chemical composition of the EOs of A. millefolium.

\begin{tabular}{|c|c|c|c|c|c|}
\hline Number & Compounds & $\begin{array}{c}\text { Molecular } \\
\text { formula }\end{array}$ & $\begin{array}{c}\text { Area } \\
(\%)\end{array}$ & Confirmed by & CAS \# \\
\hline 1 & 1-Butanol, 3-methyl-, acetate & $\mathrm{C}_{7} \mathrm{H}_{14} \mathrm{O}_{2}$ & 0.229 & STD, MS & $123-92-2$ \\
\hline 2 & Santolina triene & $\mathrm{C}_{10} \mathrm{H}_{16}$ & 0.169 & STD, MS & $2153-66-4$ \\
\hline 3 & Tricyclo[2.2.1.0(2,6)]heptane, 1,7,7-trimethyl- & $\mathrm{C}_{10} \mathrm{H}_{16}$ & 0.269 & RI, MS & $508-32-7$ \\
\hline 4 & 1R-.alpha.-Pinene & $\mathrm{C}_{10} \mathrm{H}_{16}$ & 5.114 & STD, MS & $7785-70-8$ \\
\hline 5 & Camphene & $\mathrm{C}_{10} \mathrm{H}_{16}$ & 3.998 & RI, MS & $79-92-5$ \\
\hline 6 & Benzaldehyde & $\mathrm{C}_{7} \mathrm{H}_{6} \mathrm{O}$ & 0.153 & STD, MS & $100-52-7$ \\
\hline 7 & Bicyclo[3.1.0]hexane, 4-methylene-1-(1-methylethyl) & $\mathrm{C}_{10} \mathrm{H}_{16}$ & 2.520 & STD, MS & $387-41-5$ \\
\hline 8 & Bicyclo[3.1.1]heptane, 6,6-dimethyl-2-methylene & $\mathrm{C}_{10} \mathrm{H}_{16}$ & 2.286 & RI, MS & $18172-67-3$ \\
\hline 9 & Bicyclo[3.1.1]heptane, 6,6-dimethyl-2-methylene-, (1S)- & $\mathrm{C}_{10} \mathrm{H}_{16}$ & 0.234 & STD, MS & $18172-67-3$ \\
\hline 10 & 3,5-Heptadien-2-ol, 2,6-dimethyl- & $\mathrm{C}_{9} \mathrm{H}_{16} \mathrm{O}$ & 0.144 & RI, MS & $77411-76-8$ \\
\hline 11 & 3,3,6-Trimethyl-1,4-heptadien-6-ol & $\mathrm{C}_{10} \mathrm{H}_{18} \mathrm{O}$ & 0.606 & STD, MS & $30458-12-9$ \\
\hline 12 & 1,3-Cyclohexadiene, 1-methyl-4-(1-methylethyl) & $\mathrm{C}_{10} \mathrm{H}_{16}$ & 1.239 & STD, MS & $99-86-5$ \\
\hline 13 & Benzene, 1-methyl-2-(1-methylethyl)- & $\mathrm{C}_{10} \mathrm{H}_{14}$ & 2.365 & RI, MS & $527-84-4$ \\
\hline 14 & Eucalyptol & $\mathrm{C}_{10} \mathrm{H}_{18} \mathrm{O}$ & 13.384 & STD, MS & $470-82-6$ \\
\hline 15 & Benzaldehyde, 2-hydroxy & $\mathrm{C}_{7} \mathrm{H}_{6} \mathrm{O}_{2}$ & 0.170 & RI, MS & $90-02-8$ \\
\hline 16 & 1,4-Cyclohexadiene, 1-methyl-4-(1-methylethyl) & $\mathrm{C}_{10} \mathrm{H}_{16}$ & 0.427 & STD, MS & $99-85-4$ \\
\hline 17 & Terpineol, cis-.beta & $\mathrm{C}_{10} \mathrm{H}_{18} \mathrm{O}$ & 0.519 & STD, MS & $7299-41-4$ \\
\hline 18 & 3,3,6-Trimethyl-1,5-heptadien-4-ol & $\mathrm{C}_{10} \mathrm{H}_{18} \mathrm{O}$ & 1.574 & RI, MS & $57590-19-9$ \\
\hline 19 & Bicyclo[2.2.1]heptane-2,5-diol, 1,7,7-trimethyl-, (2-endo,5-exo)- & $\mathrm{C}_{10} \mathrm{H}_{18} \mathrm{O}_{2}$ & 0.234 & STD, MS & $10359-41-8$ \\
\hline 20 & Butanoic acid, 2-methyl-, 3-methylbutyl ester & $\mathrm{C}_{10} \mathrm{H}_{20} \mathrm{O}_{2}$ & 0.466 & RI, MS & $27625-35-0$ \\
\hline 21 & Butanoic acid, 2-methyl-, 2-methylbutyl ester & $\mathrm{C}_{10} \mathrm{H}_{20} \mathrm{O}_{2}$ & 1.223 & STD, MS & $2445-78-5$ \\
\hline 22 & 2-Cyclohexen-1-ol, 4-ethyl-1,4-dimethyl & $\mathrm{C}_{10} \mathrm{H}_{18} \mathrm{O}$ & 5.715 & STD, MS & $55162-55-5$ \\
\hline 23 & Acetaldehyde, (3,3-dimethylcyclohexylidene)-, (Z)- & $\mathrm{C}_{10} \mathrm{H}_{16} \mathrm{O}$ & 20.152 & RI, MS & $26532-24-1$ \\
\hline 24 & 2-(2-Isopropenyl-5-methylcyclopentylmethoxy)tetrahydropyran & $\mathrm{C}_{15} \mathrm{H}_{26} \mathrm{O}_{2}$ & 0.814 & STD, MS & $35158-25-9$ \\
\hline 25 & Bicyclo[2.2.1]heptan-2-ol, 1,7,7-trimethyl-, (1S-endo) & $\mathrm{C}_{10} \mathrm{H}_{18} \mathrm{O}$ & 4.690 & RI, MS & $464-45-9$ \\
\hline 26 & 3-Cyclohexen-1-ol, 4-methyl-1-(1-methylethyl) & $\mathrm{C}_{10} \mathrm{H}_{18} \mathrm{O}$ & 1.751 & STD, MS & $562-74-3$ \\
\hline 27 & 3-Cyclohexene-1-methanol, .alpha.,.alpha.4-trimethyl & $\mathrm{C}_{10} \mathrm{H}_{18} \mathrm{O}$ & 4.227 & STD, MS & $98-55-5$ \\
\hline 28 & 2-Cyclohexen-1-ol, 3-methyl-6-(1-methylethyl)-, trans & $\mathrm{C}_{10} \mathrm{H}_{18} \mathrm{O}$ & 2.691 & RI, MS & $16721-39-4$ \\
\hline 29 & Fenchyl acetate & $\mathrm{C}_{12} \mathrm{H}_{20} \mathrm{O}_{2}$ & 0.811 & STD, MS & $13851-11-1$ \\
\hline 30 & 3,6-Octadien-1-ol, 3,7-dimethyl-, (Z) & $\mathrm{C}_{10} \mathrm{H}_{18} \mathrm{O}$ & 1.449 & RI, MS & $5944-20-7$ \\
\hline 31 & Bicyclo[3.1.1]hept-2-en-4-ol, 2,6,6-trimethyl-, acetate & $\mathrm{C}_{12} \mathrm{H}_{18} \mathrm{O}_{2}$ & 0.958 & RI, MS & $33522-69-9$ \\
\hline 32 & Bicyclo[3.1.1]heptane-2-methanol, 6,6-dimethyl & $\mathrm{C}_{10} \mathrm{H}_{18} \mathrm{O}$ & 1.119 & STD, MS & $514-99-8$ \\
\hline 33 & Acetic acid, 1,7,7-trimethyl-bicyclo[2.2.1]hept-2-yl ester & $\mathrm{C}_{21} \mathrm{H}_{20} \mathrm{O}_{2}$ & 0.193 & RI, MS & $92618-89-8$ \\
\hline 34 & Phenol, 2-methyl-5-(1-methylethyl) & $\mathrm{C}_{10} \mathrm{H}_{14} \mathrm{O}$ & 0.310 & STD, MS & $499-75-2$ \\
\hline 35 & 2-Cyclohexen-1-ol, 2-methyl-5-(1-methylethenyl)-, acetate, cis & $\mathrm{C}_{12} \mathrm{H}_{18} \mathrm{O}_{2}$ & 0.636 & RI, MS & $1205-42-1$ \\
\hline 36 & Phenol, 2-methoxy-5-(1-propenyl)-, (E)- & $\mathrm{C}_{10} \mathrm{H}_{12} \mathrm{O}_{2}$ & 0.188 & STD, MS & $19784-98-6$ \\
\hline 37 & Bicyclo[3.1.0]hexane, 6-isopropylidene-1-methyl & $\mathrm{C}_{10} \mathrm{H}_{16}$ & 0.545 & STD, MS & $24524-57-0$ \\
\hline 38 & 2,6-Octadien-1-ol, 3,7-dimethyl-, acetate & $\mathrm{C}_{12} \mathrm{H}_{20} \mathrm{O}_{2}$ & 0.249 & RI, MS & $16409-44-2$ \\
\hline 39 & Bicyclo[3.1.1]hept-3-en-2-one, 4,6,6-trimethyl & $\mathrm{C}_{10} \mathrm{H}_{14} \mathrm{O}$ & 0.772 & STD, MS & $80-57-9$ \\
\hline 40 & 2-Isopropylidene-3-methylhexa-3,5-dienal & $\mathrm{C}_{10} \mathrm{H}_{14} \mathrm{O}$ & 0.782 & RI, MS & $99172-18-6$ \\
\hline 41 & Caryophyllene & $\mathrm{C}_{15} \mathrm{H}_{24}$ & 4.211 & STD, MS & $87-44-5$ \\
\hline 42 & $\begin{array}{l}\text { 1H-Cycloprop[e]azulene, decahydro-1,1,7-trimethyl-4-methylene-, } \\
{[1 \mathrm{aR}-(1 \mathrm{a} . \mathrm{alph} \text {.,4a.beta.,7.alpha.,7a.beta.,7b.alpha.)]- }}\end{array}$ & $\mathrm{C}_{15} \mathrm{H}_{24}$ & 0.048 & STD, MS & $25246-27-9$ \\
\hline 43 & Caryophyllene oxide & $\mathrm{C}_{15} \mathrm{H}_{24} \mathrm{O}$ & 3.573 & RI, MS & $1139-30-6$ \\
\hline 44 & beta.-Guaiene & $\mathrm{C}_{15} \mathrm{H}_{24}$ & 1.389 & STD, MS & $88-84-6$ \\
\hline Total & - & - & 94.580 & - & - \\
\hline
\end{tabular}

STD: confirmed by injection of standard and by mass spectra library; MS: tentative identification, confirmation only by mass spectra library; RI: confirmed by $n$-alkanes retention index by mass spectra library. 
Table 2 Chemical composition of the EOs of F. kuma.

\begin{tabular}{|c|c|c|c|c|c|}
\hline Number & Compounds & $\begin{array}{l}\text { Molecular } \\
\text { formula }\end{array}$ & $\begin{array}{l}\text { Area } \\
(\%)\end{array}$ & Confirmed by & CAS \# \\
\hline 1 & Tricyclo[2.2.1.0(2,6)]heptane, 1,7,7-trimethyl & $\mathrm{C}_{10} \mathrm{H}_{16}$ & 1.332 & STD, MS & $508-32-7$ \\
\hline 2 & 1R-.alpha.-Pinene & $\mathrm{C}_{10} \mathrm{H}_{16}$ & 18.764 & RI, MS & $7785-70-8$ \\
\hline 3 & Camphene & $\mathrm{C}_{10} \mathrm{H}_{16}$ & 13.915 & STD, MS & $79-92-5$ \\
\hline 4 & Bicyclo[3.1.1] heptane, 6,6-dimethyl-2-methylene-, (1S)- & $\mathrm{C}_{10} \mathrm{H}_{16}$ & 3.116 & RI, MS & $18172-67-3$ \\
\hline 5 & beta.-Myrcene & $\mathrm{C}_{10} \mathrm{H}_{16}$ & 3.319 & STD, MS & $123-35-3$ \\
\hline 6 & Limonene & $\mathrm{C}_{10} \mathrm{H}_{16}$ & 3.105 & STD, MS & $138-86-3$ \\
\hline 7 & Cyclohexanol, 1-methyl-4-(1-methylethenyl)-, acetate & $\mathrm{C}_{12} \mathrm{H}_{20} \mathrm{O}_{2}$ & 3.214 & STD, MS & 10198-23-9 \\
\hline 8 & $\begin{array}{l}\text { Bicyclo[3.1.1]hept-3-en-2-ol, 4,6,6-trimethyl-, [1S-(1. } \\
\text { alpha.,2.beta.,5.alpha.)]- }\end{array}$ & $\mathrm{C}_{10} \mathrm{H}_{16} \mathrm{O}$ & 2.210 & MS & 18881-04-4 \\
\hline 9 & Fenchyl acetate & $\mathrm{C}_{12} \mathrm{H}_{20} \mathrm{O}_{2}$ & 18.993 & RI, MS & $13851-11-1$ \\
\hline 10 & $\begin{array}{l}\text { Bicyclo[2.2.1]heptan-2-ol, 1,7,7-trimethyl-, acetate, } \\
\text { (1S-endo)- }\end{array}$ & $\mathrm{C}_{12} \mathrm{H}_{20} \mathrm{O}_{2}$ & 23.154 & RI, MS & $5655-61-8$ \\
\hline 11 & 2,6-Octadiene, 2,6-dimethyl- & $\mathrm{C}_{10} \mathrm{H}_{18}$ & 1.320 & STD, MS & 2792-39-4 \\
\hline 12 & Caryophyllene & $\mathrm{C}_{15} \mathrm{H}_{24}$ & 3.758 & STD, MS & $87-44-5$ \\
\hline 13 & Benzene, 1-(1,5-dimethyl-4-hexenyl)-4-methyl- & $\mathrm{C}_{15} \mathrm{H}_{22}$ & 1.240 & RI, MS & $644-30-4$ \\
\hline 14 & Caryophyllene oxide & $\mathrm{C}_{15} \mathrm{H}_{24} \mathrm{O}$ & 5.775 & RI, MS & $1139-30-6$ \\
\hline Total & - & - & 96.55 & - & - \\
\hline
\end{tabular}

STD: confirmed by injection of standard and by mass spectra library; MS: tentative identification, confirmation only by mass spectra library; RI: confirmed by $n$-alkanes retention index by mass spectra library.

Table 3 Chemical composition of the EOs of M. longifolia.

\begin{tabular}{|c|c|c|c|c|c|}
\hline Number & Compounds & $\begin{array}{l}\text { Molecular } \\
\text { formula }\end{array}$ & $\begin{array}{c}\text { Area } \\
(\%)\end{array}$ & Confirmed by & CAS \# \\
\hline 1 & Eucalyptol & $\mathrm{C}_{10} \mathrm{H}_{18} \mathrm{O}$ & 14.569 & STD, MS & $470-82-6$ \\
\hline 2 & Cyclohexanone, 5-methyl-2-(1-methylethyl)- & $\mathrm{C}_{10} \mathrm{H}_{18} \mathrm{O}$ & 3.852 & STD, MS & $10458-14-7$ \\
\hline 3 & Cyclohexanone, 5-methyl-2-(1-methylethylidene)- & $\mathrm{C}_{10} \mathrm{H}_{16} \mathrm{O}$ & 35.391 & RI, MS & $15932-80-6$ \\
\hline 4 & Bicyclo[3.1.1]hept-3-en-2-one, 4,6,6-trimethyl- & $\mathrm{C}_{10} \mathrm{H}_{14} \mathrm{O}$ & 43.412 & STD, MS & $80-57-9$ \\
\hline 5 & Caryophyllene oxide & $\mathrm{C}_{15} \mathrm{H}_{24} \mathrm{O}$ & 2.766 & RI, MS & $1139-30-6$ \\
\hline Total & - & - & 99.990 & - & - \\
\hline
\end{tabular}

STD: confirmed by injection of standard and by mass spectra library; MS: tentative identification, confirmation only by mass spectra library; RI: confirmed by $n$-alkanes retention index by mass spectra library.

phaeae. The inhibition effect of mycelial growth was positively correlated with the concentration of EOs (Fig. 1). The results showed that EOs of $M$. longifolia $\left(\mathrm{EC}_{50}=26.08\right.$ $\mu \mathrm{L} / \mathrm{L})$ appear to be more toxic than A. millefolium $\left(\mathrm{EC}_{50}=\right.$ $60.31 \mu \mathrm{L} / \mathrm{L})$, Captan fungicide $\left(\mathrm{EC}_{50}=62.97 \mu \mathrm{L} / \mathrm{L}\right)$, and $F$. kuma $\left(\mathrm{EC}_{50}=65.06 \mu \mathrm{L} / \mathrm{L}\right)$ against $C$. nymphaeae (Table 5). The EOs of $F$. kuma showed the lowest inhibitory effects against pathogen. Antifungal activity of EOs against different plant pathogens using contact and vapor phase has been reported in previous works ${ }^{30-33)}$. The mycelial growth of $C$. musae causal agent of anthracnose of banana fruit was inhibited by Cinnamon oil and clove oil ${ }^{34}$. Application of EOs on subtropical fruit such as avocado and mango de- creased the anthracnose incidence caused by C. gloeosporioides on these fruits ${ }^{9,35)}$.

The results of the in vitro experiment indicated that all EOs strongly inhibited the conidial germination of C. nymphaeae after $48 \mathrm{~h}$ in both methods. In contact and vapor methods, the reduction of germinated conidial of C. nymphaeae was $79.2 \%$ to $84.6 \%$ and $67.2 \%$ to $90 \%$, respectively, compared to the control treatment(Table 4). In the control treatment, spores of C. nymphaeae germinated and produced the germ tube that gradually developed to long hyphae (data are not shown). In the contact method, there was no significant difference in the treatment of $M$. longifolia, A. millefolium, F. kuma EOs, and Captan. The 
Table 4 In vitro conidial germination inhibition of essential oils against $C$. nymphaeae using contact and vapour methods after 7 days.

\begin{tabular}{lcccc}
\hline \multicolumn{1}{c}{ Treatments } & \multicolumn{2}{c}{ Contact method } & \multicolumn{2}{c}{ Vapour method } \\
& $\begin{array}{c}\text { Number of germinated } \\
\text { conidia }\end{array}$ & Inhibition percent (\%) & $\begin{array}{c}\text { Number of germinated } \\
\text { conidia }\end{array}$ & Inhibition percent (\%) \\
\hline Control pathogen & $193.75 \pm 2.28 \mathrm{a}$ & - & $187.50 \pm 2.39 \mathrm{a}$ & - \\
A. millefolium & $29.75 \pm 0.29 \mathrm{~b}$ & 84.6 & $18.75 \pm 3.16 \mathrm{e}$ & 90.0 \\
M. longifolia & $36.25 \pm 0.94 \mathrm{~b}$ & 81.3 & $29.25 \pm 2.75 \mathrm{~d}$ & 84.4 \\
F. kuma & $40.25 \pm 1.03 \mathrm{~b}$ & 79.2 & $49.25 \pm 1.25 \mathrm{c}$ & 73.7 \\
Captan & $34.75 \pm 0.71 \mathrm{~b}$ & 82.1 & $61.5 \pm 1.75 \mathrm{~b}$ & 67.2 \\
\hline
\end{tabular}

Concentration of Achillea millefolium, Mentha longifolia, Ferula kuma EOs and fungicide was used at 1500, 600, 1850 and $2100 \mu \mathrm{L} / \mathrm{L}$ respectively. Means $\pm \mathrm{SE}$ in the same column with different letters are significantly different $(p \leq 0.05)$ according to Duncan multiple-ranges test (DMRT).

Table $5 \quad \mathrm{EC}_{50}$ of EOs and fungicide on C. nymphaeae (at Confidence limit 95\%).

\begin{tabular}{lccccc}
\hline \multicolumn{1}{c}{ Treatment } & $\mathrm{EC}_{50}(\mu \mathrm{L} / \mathrm{L})$ & $\mathrm{a}$ & $\mathrm{b}^{2}$ & $\mathrm{X}^{2}$ & $\mathrm{R}^{2}$ \\
\hline M. longifolia & 26.08 & $1.83 \pm 0.16$ & $-4.43 \pm 0.41$ & 18.51 & 0.90 \\
A. millefolium & 60.31 & $1.46 \pm 0.15$ & $-4.08 \pm 0.42$ & 21.20 & 0.81 \\
F. kuma & 65.06 & $2.30 \pm 0.18$ & $-6.48 \pm 0.52$ & 44.30 & 0.85 \\
Captan & 62.97 & $2.14 \pm 0.17$ & $-6.01 \pm 0.52$ & 4.71 & 0.98 \\
\hline
\end{tabular}

$\mathrm{EC}_{50}=$ median effective inhibitory concentration; $\mathrm{a}=$ Slope; $\mathrm{b}^{2}=$ Intercept $\mathrm{X}^{2}=$ Chi-Square; $\mathrm{R}^{2}=$ Correlation coefficient.

EOs of A. millefolium had the most effect on reduction of conidial germination of the pathogen after $48 \mathrm{~h}$ in contact and vapor methods (Table 4). The conidial germination of C. coccodes on infected tomato fruits was decreased by Origanum oil treatment in vitro ${ }^{36)}$. Inhibition of the mycelial growth and conidial germination of $C$. gloeosporioides causal agent of pepper fruit anthracnose was inhibited by vapor treatment with $\mathrm{EOs}^{8}{ }^{8} \mathrm{Also}$, the conidial germination and mycelial growth of $B$. cinerea and Fusarium proliferatum were inhibited using cinnamon oil ${ }^{37)}$.

\subsection{Scanning electron microscopy analysis}

The EOs in the culture medium revealed that mycelia of C. nymphaeae were different from those of the control treatment. The mycelia morphology of $C$. nymphaeae in control treatment was regular, smooth and uniform. In comparison, the mycelia in treatments by EOs were abnormal due to its thick, irregular swelling. In addition, structures of fungal mycelia appeared depressed and collapsed (Fig. 2) . Similarly ${ }^{38)}$, the investigation of the mycelium of Alternaria alternate treated with Syringa ablata EO, showed considerable morphological alterations. The SEM analysis indicated that mycelium treated with eugenol was shrunken compared to the control ${ }^{39)}$.

\subsection{Antifungal activity tests in vivo and greenhouse con- ditions}

The efficacy of the EOs in decay rate in strawberry fruits in vivo presented in Table 6 . The disease index in control treatment after 10 days reached 4.75 . The postharvest decay was significantly decreased when strawberry fruit was treated with EOs as compared to the $\operatorname{control}(p \leq$ $0.05)$. Among these results, $M$. longifolia EO was most effective with over $98.7 \%$ reduction in disease severity (Table 6). Anthracnose, caused by C. nymphaeae, is the most aggressive disease of strawberry and limits good fruit quality $^{1)}$. The results obtained in this work were reflected in other investigations, where it was reported that EOs attributes to the decreased postharvest decay in several fruit such as apricots and plums ${ }^{40)}$, strawberries $^{43)}$, bananas $^{11)}$, pomegranates ${ }^{22)}$ and peppers ${ }^{8}$. The pepper fruit anthracnose was reduced by application of EOs on pepper fruits ${ }^{8)}$. Thyme oil reduced postharvest decay in several fruits such as apricots and plums ${ }^{40)}$, citrus ${ }^{42)}$, strawberries ${ }^{41)}$ and oranges ${ }^{7)}$. The EOs increased the phenolic compounds in plants and prevents the growth of pathogens as well as declining the severity of fruit decay ${ }^{7}$.

The results of the greenhouse test are reported in Table 6. Disease index was measured after two months. In greenhouse conditions, symptoms of anthracnose on petioles appeared 40 days after inoculation in control pathogen. All EOs and fungicides significantly $(p \leq 0.05)$ decreased the 


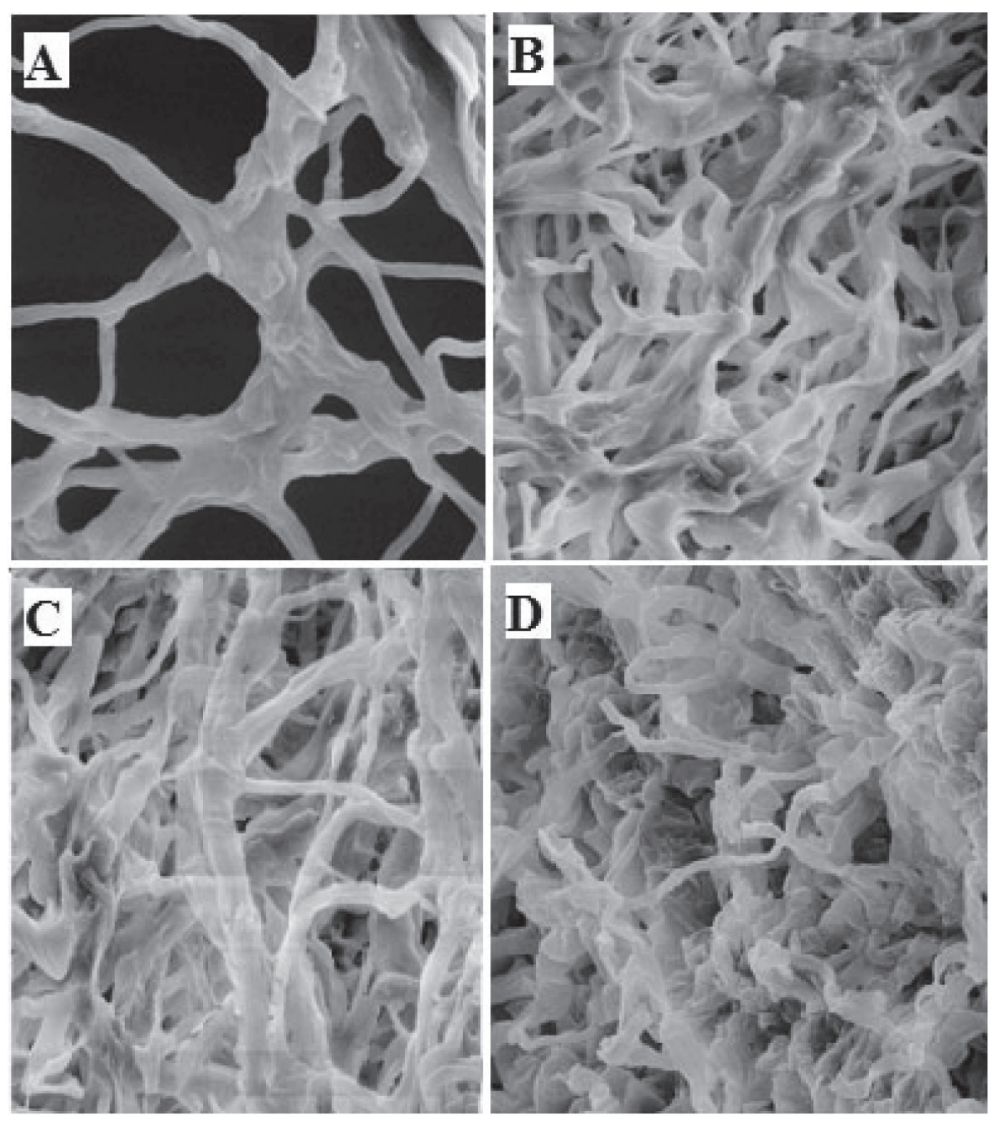

Fig. 2 Morphological changes of C. nymphaeae hyphae treated with A. millefolium EO(B), M. longifolia EO(C) and F. kuma EO(D) observed through Scanning electron microscopy. Structures of fungal mycelia treated with EOs appeared depressed and collapsed. Mycelia in control treatment(A) showed a regular, linear and uniform shape.

Table 6 Effect of EOs and fungicide on fruit decay development in vivo using vapour method after 7 days and disease severity in greenhouse conditions after 60 days.

\begin{tabular}{lcccc}
\hline \multicolumn{1}{c}{ Treatments } & \multicolumn{2}{c}{ In vivo } & \multicolumn{2}{c}{ Greenhouse } \\
\hline & Disease severity & $\begin{array}{c}\text { Control efficacy } \\
(\%)\end{array}$ & Disease severity & $\begin{array}{c}\text { Control efficacy } \\
(\%)\end{array}$ \\
\hline Control pathogen & $4.75 \pm 0.10 \mathrm{a}$ & - & $4.33 \pm 0.22 \mathrm{a}$ & - \\
A. millefolium & $0.31 \pm 0.62 \mathrm{~b}$ & 93.5 & $0.75 \pm 0.14 \mathrm{bc}$ & 82.7 \\
M. longifolia & $0.06 \pm 0.06 \mathrm{c}$ & 98.7 & $0.33 \pm 0.22 \mathrm{~cd}$ & 92.4 \\
F. kuma & $0.40 \pm 0.07 \mathrm{~b}$ & 91.6 & $1.08 \pm 0.83 \mathrm{~b}$ & 75.1 \\
Captan & $1.05 \pm 0.06 \mathrm{~b}$ & 77.9 & $0.50 \pm 0.14 \mathrm{c}$ & 88.4 \\
\hline
\end{tabular}

Concentration of Achillea millefolium, Mentha longifolia, Ferula kuma EOs and fungicide was used at $1500,600,1850$ and $2100 \mu \mathrm{L} / \mathrm{L}$ respectively. Data were based on Mean \pm standard error (SE) in the same column with different letters are significantly different $(p \leq 0.05)$ according to Duncan multiple-ranges test (DMRT).

disease severity and increased control efficacy compared with the untreated control. Fungicide of Captan reduced the disease severity of $88.4 \%$. EO of $M$. longifolia was the most effective with over $92.4 \%$ reduction in disease severity, followed by A. millefolium and F. kuma with $82.7 \%$ and $75.1 \%$ reduction, respectively (Table 6). Application of
EOs against soil born pathogen ${ }^{15,43)}$, foliar fungal disease ${ }^{8,38)}$, and postharvest disease ${ }^{7,10,11,20)}$ was reported by other researchers. The high rate of phenolic compounds including thymol and carvacrol in plant essential oils prevents the growth of a fungal colony of Alternaria citri causal agent of orange black rot and reduces the severity of decay ${ }^{7}$. 
Table 7 Effect of EOs and fungicide on strawberry fruit quality after 8 days storage period.

\begin{tabular}{|c|c|c|c|}
\hline Paros cultivar & Treatments & Spray time & D8 \\
\hline \multirow[t]{5}{*}{ Weight loss \% } & Control & $0 \pm 0 \mathrm{~b}$ & $0.41 \pm 0.14 b$ \\
\hline & A. millefolium & & $0.43 \pm 0.12 b$ \\
\hline & M. longifolia & & $0.41 \pm 0.02 \mathrm{~b}$ \\
\hline & F. kuma & & $0.82 \pm 0.23 \mathrm{a}$ \\
\hline & Captan & & $0.38 \pm 0.10 \mathrm{~b}$ \\
\hline \multirow[t]{5}{*}{ Firmness (N) } & Control & $4.56 \pm 0.49 \mathrm{a}$ & $3.20 \pm 0.20 \mathrm{c}$ \\
\hline & A. millefolium & & $2.99 \pm 0.58 \mathrm{~d}$ \\
\hline & M. longifolia & & $3.92 \pm 0.48 \mathrm{bc}$ \\
\hline & F. kuma & & $3.25 \pm 0.72 \mathrm{c}$ \\
\hline & Captan & & $3.25 \pm 0.72 \mathrm{c}$ \\
\hline \multirow[t]{5}{*}{ Vitamin C (mg/100 g FFW) } & Control & $25.59 \pm 2.78 \mathrm{a}$ & $21.13 \pm 3.01 \mathrm{a}$ \\
\hline & A. millefolium & & $22.96 \pm 1.41 \mathrm{a}$ \\
\hline & M. longifolia & & $24.13 \pm 1.11 \mathrm{a}$ \\
\hline & F. kuma & & $24.37 \pm 0.43 \mathrm{a}$ \\
\hline & Captan & & $23.30 \pm 1.28 \mathrm{a}$ \\
\hline \multirow[t]{5}{*}{ Total phenol content (mg/100 g FFW) } & Control & $156.32 \pm 20.27 \mathrm{~b}$ & $219.96 \pm 8.88 \mathrm{a}$ \\
\hline & A. millefolium & & $226.12 \pm 10.09 \mathrm{a}$ \\
\hline & M. longifolia & & $209.30 \pm 10.38 \mathrm{a}$ \\
\hline & F. kuma & & $239.37 \pm 10.52 \mathrm{a}$ \\
\hline & Captan & & $215 \pm 24.03 \mathrm{a}$ \\
\hline \multirow[t]{5}{*}{ Antioxidant activity (DPPH \%) } & Control & $76.73 \pm 1.83 \mathrm{a}$ & $71.04 \pm 0.26 \mathrm{ab}$ \\
\hline & A. millefolium & & $67.25 \pm 2.07 \mathrm{~b}$ \\
\hline & M. longifolia & & $76.77 \pm 0.98 \mathrm{a}$ \\
\hline & F. kuma & & $69.42 \pm 0.38 b$ \\
\hline & Captan & & $76.04 \pm 2.30 \mathrm{a}$ \\
\hline \multirow[t]{5}{*}{ Peroxidase activity (Unit/g FFW) } & Control & $0.094 \pm 0.06 \mathrm{c}$ & $0.60 \pm 0.03 \mathrm{ab}$ \\
\hline & A. millefolium & & $0.72 \pm 0.08 \mathrm{a}$ \\
\hline & M. longifolia & & $0.54 \pm 0.02 b$ \\
\hline & F. kuma & & $0.65 \pm 0.09 \mathrm{ab}$ \\
\hline & Captan & & $0.63 \pm 0.01 \mathrm{ab}$ \\
\hline
\end{tabular}

The values are means \pm standard error (SE). Data in the same column with different letters represent significant difference $(p \leq 0.01)$ according to Duncan multiple-ranges test.

\subsection{Fruit quality analyses}

The effect of EOs and fungicide on fruit quality is shown in Table 7.

\subsubsection{Weight loss}

The weight loss of strawberry fruit in any of the treatments (except F. kuma EOs) was not affected by EOs and increased gradually throughout the storage period. There was no significant difference between the treatments of EOs (except F. kuma EOs) and control. EOs of F. kuma decreased weight loss $(0.82 \%)$ than control significantly $(p$ $\leq 0.01$ ) after 8 days of storage (Table 7 ). The results ob- tained in this study are in line with those of other works, where weight loss of lettuce was not affected by thyme $\mathrm{EO}^{44)}$. Thyme oil prevented weight loss of banana and grape berries ${ }^{11,45)}$. Moreover, it has been shown that a high temperature leads to an increase in the respiration rate of the fruit and weight $\operatorname{loss}^{46)}$.

3.5.2 Fruit firmness

Fruit firmness is one of the most important quality deterioration characters during storage time, which is caused by the degradation of pectin in the fruit cell wall and hydrolysis of starch to sugar associated with fruit ripening ${ }^{47}$. 
The preservation of fruit firmness is an important factor for increasing storage life of fresh products and reductions in fruit firmness lead to the declined quality of fruit ${ }^{48)}$. Results of this study indicated that fruit firmness was decreased through storage time in all treatments $(p \leq 0.01)$ (Table 7 ). All fruits treated with the EOs (except A. millefolium) were firmer than the control fruit. The highest and the lowest strawberry firmness values were found in $M$. longifolia EO and A. millefolium with $3.92 \mathrm{~N}$ and $2.99 \mathrm{~N}$, respectively (Table 7). Similar values were reported by Anthony et $a l .{ }^{13)}$, using the effect EOs of Cymbopogon nardus and Ocimum basilicum on the firmness of banana fruit. Plant EOs reduced the activity of the softening enzymes in the cell wall components including polygalacturonase and galactosidase and preserved the fruit firmness during the storage $\mathrm{e}^{7)}$.

3.5.3 Ascorbic acid

The ascorbic acid (vitamin $\mathrm{C}$ ) rate was reduced in all treatments after 8 days, but no significant differences $(p \leq$ 0.01 ) were found between the treatments of EOs and control treatment at the first and end of storage period. The vitamin $\mathrm{C}$ content in EOs was more than control treatment until the end of the cold storage (Table 7). This study showed that EOs caused maintains vitamin $\mathrm{C}$ content in fruit during storage probably due to the antioxidant effects of $\mathrm{EOs}^{7)}$.

3.5.4 Total phenol content (TPC)

A general increase in TPC was observed for all treatments $(p \leq 0.01)$ while no significant differences were found between the treatments and control at end of the storage period (Table 7). The TPC rate in control treatment was $219.96 \mathrm{mg}$ gallic acid per $100 \mathrm{~g}$ fruit fresh at the end of storage period. Thus, there were significantly higher levels of TPC in fruit inoculated with EOs compared to spray time after 8 days storage. The most and the least total phenol was found in fruit treated with F. kuma (239.37 $\mathrm{mg} / 100 \mathrm{~g}$ ) and $M$. longifolia (209.30 mg/100 g), respectively, after 8 days of cold storage. The phenol compounds can be found in EOs, which play a very good role in plant health and are an important quality factor in fruits and vegetables ${ }^{47)}$. They have a direct relationship at reduction decay severity of fruits and the management of postharvest diseases ${ }^{49)}$. Results indicated that phenolic compounds in Ocimum basilicum increased the antioxidant activity in plant and then induced the defense system of the plant against plant pathogens ${ }^{50)}$.

3.5.5 Antioxidant activity

After 8 days of storage, a DPPH value was decreased in all treatments, except for M. longifolia and Captan Fungicide. The DPPH value of strawberry fruits in control treatment at end of storage period was $71.04 \%$. M. longifolia $\mathrm{EO}(76.77 \%)$ and Captan $(76.04 \%)$ gave the higher antioxidant values, respectively, but no significant difference was observed between them and control at first days of the storage (Table 7). A previous study has shown that EOs possess antioxidant properties ${ }^{51)}$. It has been well documented that reduction of vitamin $\mathrm{C}$ and anthocyanin in fruits through time leads to a decrease in the antioxidant activity in plants ${ }^{52)}$ and, at least, may induce the fruit decay $^{53)}$.

3.5.6 Peroxidase (POD) activity

During the whole storage period, a more rapid increase in POD activity was observed in all treatments. The POD activity was different in the treatments. The POD activities of the strawberry fruits treated by A. millefolium EO and F. kuma EO were higher compared to the other treatments (Table 7). POD is an important resistance-related enzyme in fruit as a plant defense mechanism and plays an important role during postharvest storage in the protection of fruits against postharvest disease $\mathrm{e}^{54-56)}$.

\subsection{Sensory evaluation}

The sensory evaluation showed that sensory parameters except the taste were not affected by treatments. The greatest and the lowest scores in the taste attribute were 3.09 and 2.09, which belong to M. longifolia and F. kuma treatment, respectively. The A. millefolium and control scores in the taste attributes were 2.90 and 2.63, respectively (data are not shown). M. longifolia EO at $600 \mu \mathrm{L} / \mathrm{L}$ was the best treatment in reducing the decay produced by C. nymphaeae in strawberry fruit and maintaining the physicochemical parameters during cold storage. It has been reported that use of thyme oil in avocadoes and organic bananas retained the texture, flavor, overall appearance, and odor of the fruits ${ }^{9,11)}$. In addition, the study showed that EO did not affect the appearance, flavor and overall acceptability in strawberry fruits ${ }^{57)}$.

\section{Conclusion}

In conclusion, the results of this research showed a positive effect of EOs on reduction of fruit decay during the storage period. In addition, EOs were effective in maintaining the physicochemical and sensory qualities of strawberry fruit. Therefore, these results are an important step toward the goal of using EOs of Achillea millefolium, Ferula kuma, and Mentha longifolia as bio-fungicide to the management of the pathogen $C$. nymphaeae of strawberry. However, further research is needed to confirm the findings and combination of EOs with other methods may be hopeful for integrated control of strawberry anthracnose disease.

\section{Acknowledgment}

The authors are thankful to Department of plant Protec- 
tion, University of Kurdistan for providing financial and technical support for our research under grant (No 19/29435).

\section{Conflict of Interest}

The authors declare that they have no conflict of interest.

\section{References}

1) Karimi, K.; Babai Ahari, A.; Arzanlou, M.; Amini, J.; Pertot, I.; Rota-Stabelli, O. Application of the consolidated species concept to identify the causal agent of strawberry anthracnose in Iran and initial molecular dating of the Colletotrichum acutatum species complex. J. Plant Pathol. 147, 375-387 (2017).

2) Baroncelli, R.; Zapparata, A.; Sarrocco, S.; Sukno, S.A.; Lane, C.R.; Thon, M.R.; Vannacci, G.; Holub, E.; Sreenivasaprasad, S. Molecular diversity of anthracnose pathogen populations associated with UK strawberry production suggests multiple introductions of three different Colletotrichum species. PloS One 10, 0129140 (2015).

3) Mlikota Gabler, F.; Smilanick, J.I. Postharvest control of table grape gray mold on detached berries with carbonate and bicarbonate salts and disinfectants. $J$. Enol. Viticul. 52, 12-20 (2001).

4) Porras, P.; Barrau, C.; Romero, F. Effect of soil solarization and Trichoderma on strawberry production. Crop Protec. 26, 782-787 (2007).

5) Shao, X.F.; Cao, B.Y.; Xu, F.; Xi, S.H.; Yu, D.D.; Wang, H.F. Effect of postharvest application of chitosan combined with clove oil against citrus green mold. Postharvest Biol. Technol. 99, 37-43(2015).

6) Romanazzi, G.; Sanzani, S.M.; Bi, Y.; Tian, S.; Gutierrez-Martinez, P.; Alkan, N. Induced resistance to control postharvest decay of fruit and vegetables. Postharvest Biol. Technol. 122, 82-94(2016).

7) Ramezanian, A.; Azadi, M.; Mostowizadeh-Ghalamfarsa, R.; Saharkhiz, M.J. Effect of Zataria multiflora Bioss and Thymus vulgaris L. essential oils on black rot of Washington Navel orange fruit. Postharvest Biol. Technol. 112, 152-158(2016).

8) Hong, J.K.; Yang, H.J.; Jung, H.; Yoon, D.J.; Sang, M.K.; Jeun, Y.C. Application of volatile antifungal plant essential oils for controlling pepper fruit anthracnose by Colletotrichum gloeosporioides. J. Plant Pathol. 31, 269-277 (2015).

9) Sellamuthu, P.S.; Mafune, M.;Sivakumar, D.; Soundy, P. Thyme oil vapor and modified atmosphere packaging reduce anthracnose incidence and maintain fruit qual- ity in avocado. J. Sci. Food Agric. 93, 3024-3031 (2013).

10) Servili, A., Feliziani, E.; Romanazzi, G. Exposure to volatiles of essential oils alone or under hypobaric treatment to control postharvest gray mold of table grapes. Postharvest Biol. Technol. 133, 36-40 (2017).

11) Vilaplana, R.; Pazmino, L.; Valencia-Chamorro, S. Control of anthracnose, caused by Colletotrichum musae, on postharvest organic banana by thyme oil. Postharvest Biol. Technol. 138, 56-63(2018).

12) Munhuweyi, K.; Caleb, O.J.; Lennox, C.L.; van Reenen, A.J.; Opara, U.L. In vitro and in vivo antifungal activity of chitosan-essential oils against pomegranate fruit pathogens. Postharvest Biol. Technol. 129, 9-22 (2017).

13) Anthony, S.; Abeywickrama, K.; Wijeratnam, S.W. The effect of spraying essential oils of Cymbopogon nardus, Cymbopogon flexuosus and Ocimum basilicum on postharvest diseases and storage life of Embul banana. J. Hortic. Sci. Biotechnol. 78, 780-785 (2003).

14) Demirci, B.; Baser, K.H.; Tabanca, N.; Wedge, D.E. Characterization of volatile constituents of Haplopappus greenei and studies on the antifungal activity against phytopathogens. J. Agric. Food Chem. 54, 3146-3150 (2006).

15) Amini, J.; Farhang, V.; Javadi, T.; Nazemi, J. Antifungal effect of plant essential oils on controlling phytophthora species. J. Plant. Pathol. 32, 16-24 (2016)

16) Pimentel, R.B.O.; Souza, D.P.; Albuquerque, P.M.; Fernandes, A.V.; Santos, A.S.; Duvoisi, S.; Goncalves, J.F.C. Variability and antifungal activity of volatile compounds from Aniba rosaeodora Ducke, harvested from Central Amazonia in two different seasons. Ind. Crops Prod. 123, 1-9 (2018).

17) Ozcan, M.M.; Chalchat, J.C.; Arslan, D.; Ates, A.; Unever, A. Comparative essential oil composition and antifungal effect of bitter fennel(Foenichlum vulgare ssp. Piperitum) fruit oils obtained during different vegetation. J. Med. Food 9, 552-561(2006).

18) Soylu, E.M.; Soylu, S.; Kurt, S. Antimicrobial activities of the essential oils of various plants against tomato late blight disease agent Phytophthora infestans. Mycopathol. 161, 119-128(2006).

19) Xing, Y.; Li, X.; Xu, Q.; Yun, J.; Lu, Y. Antifungal activities of cinnamon oil against Rhizopus nigricans, Aspergillus flavus and Penicillium expansum in vitro and in vivo fruit test. J. Food Sci. Technol. 45, 1837$1842(2010)$.

20) Thomidis, T.; Filotheou, A. Evaluation of five essential oils as bio-fungicides on the control of Pilidiella granati rot in pomegranate. Crop Protec. 89, 66-71 (2016)

21） Larran, S.; Simón, M.R.; Moreno, M.V.; Santamarina Siurana, M.P.; Perelló, A. Endophytes from wheat as bio- 
control agents against tan spot disease. Biol. Control. 92, 17-23(2016).

22) Naureen, Z.; Price, A.H.; Hafeez, F.Y.; Roberts, M.R. Identification of rice blast disease-suppressing bacterial strains from the rhizosphere of rice grown in Pakistan. Crop Protec. 28, 1052-1060 (2009).

23) Huang, R.; Li, G.Q.; Zhang, J.;Yang, I.; Che, H.J.; Jiang, D.H.; Huang, H.C. Control of postharvest Botrytis fruit rot of strawberry by volatile organic compound of Candida intermedia. Phytopathol. 101, 859-869 (2011).

24) Delp, B.; Milholland, R. Evaluation strawberry plants for resistance to Colletotrichum fragariae. Plant Disease 64, 1071-1073(1980).

25) Kevers, C.; Falkowski, M.; Tabart, J.; Defraigne, J.O.; Dommes, J.;Pincemail, J. Evolution of antioxidant capacity during storage of selected fruits and vegetables. J. Agric. Food Chem. 55, 8596-8603 (2007).

26) Singleton, V.L.; Orthofer, R.; Lamuela-Raventos, R.M. Analysis of total phenols and other oxidation substrates and antioxidants by means of folin-ciocalteu reagent. Methods in Enzymol. 299, 152-178(1999).

27) Patras, A.; Brunton, N.P.; Da Pieve, S.; Butler, F. Impact of high pressure processing on total antioxidant activity, phenolic, ascorbic acid, anthocyanin content and colour of strawberry and blackberry purées. Food Sci. Emerging Technol. 10, 308-313(2009).

28) Ghanati, F.; Morita, A.; Yokota, H. Induction of suberin and increase of lignin content by excess boron in tobacco cells. Soil Sci. Plant Nutri. 48, 357-364(2002).

29) Lu, H.; Ban, Z.; Wang, K.; Li, D.; Poverenov, E.; Li, I.; Luo, Z. Aroma volatiles sensory and chemical attributes of strawberry (Fragaria $\times$ ananasa Duch.) achenes and receptacle. J. Food Sci. Technol. 52, 2614-2622 (2017).

30) Lopez, P.; Sanchez, C.; Batlle, R.; Nerin, C. Solid and vapor-phase antimicrobial activities of six essential oils: susceptibility of selected foodborne bacterial and fungal strains. J. Agric. Food Chem. 53, 6939-4946 (2005).

31) Ma, B.X.; Ban, X.Q.; He, J.S.; Huang, B.; Zeng, H.; Tian, J.; Wang, Y.W. Antifungal activity of Ziziphora clinopodioides Lam. essential oil against Sclerotinia sclerotiorum on rapeseed plants (Brassica campestris L.). Crop Protec. 89, 289-295 (2016).

32) Singh, G.; Maurya, S.; De lampasona, M.P.; Catalan, C. Chemical constituents, antimicrobial investigations, and anti-oxidative potentials of Anethum graveolens L. essential oil and acetone extract. J. Food Sci. 70, 208-215 (2005).

33) Jobling, J. Essential oils: a new idea for postharvest disease control. Good Fruit Veg. Magaz. 11, 50 (2000).

34) Ranasinghe, L.; Jayawardena, B.; Abeywickrama, K.
Fungicidal activity of essential oils of Cinnamomum zeylanicum (L.) and Syzygium aromatichum(L.) Merr et L.M. Perry against crown rot and anthracnose pathogens isolated from banana. Lett. Appl. Microbiol. 35, 208-211 (2002).

35) Abd-Alla, M.A.; Haggag, W.M. Use of some plant essential oils as post-harvest botanical fungicides in the management of anthracnose disease of mango fruits (Mangifera indica L.) caused by Colletotrichum gloeosporioides (Penz). J. Agric. Forestry 3, 1-6 (2013).

36) Tzortzakis, N.G.; Tzanakaki, K.; Economaki, C.D. Effect of origanum oil and vinegar on the maintenance of postharvest quality of tomato. Food Nutri. Sci. 2, 974 (2011).

37) Wilson, C.L.; Solar, J.M.; El Ghaouth, A.; Wisniewski, M.E. Rapid evaluation of plant extract and essential oils for antifungal activity against Botrytis cinerea. Plant Disease 81, 204-210 (1997).

38) Jing, C.; Zhao, J.; Han, X.; Huang, R.; Cai, D.; Zhang, C. Essential oil Syringa oblate Lindl. As a potential biocontrol agent against tobacco brown spot caused by Alternaria alternate. Crop Protec. 104, 41-46 (2018).

39) Zhou, H.; Tao, N.; Jia, L. Antifungal activity of citral, octanal and $\alpha$-terpineol against Geotrichum citri-aurantii. Food Control 37, 277-283(2014).

40) Liu, W.; Chu, C.; Zhou, T. Thymol and acetic acid vapors reduce postharvest brown rot of apricots and plums. HortSci. 37, 151-156 (2002).

41) Campos-Requena, V.H.; Rivas, B.I.; Perez, M.A.; Figueroa, C.R.; Figueroa, N.E.; Sanfuentes, E.A. Thermoplastic atarch/clay nanocomposites loaded with essential oil constituents as packaging for strawberries in vitro antimicrobial synergy over Botrytis cinerea. Postharvest Biol. Technol. 129, 29-36 (2017).

42) Plaza, P.; Torres, R.; Usall, J.; Lamarca, N.; Vinas, I. Evaluation of the potential of commercial post-harvest application of essential oils to control citrus decay. $J$. Hortic. Sci. Biotechnol. 79, 935-940 (2004).

43) La Torre, A.; Caradonia, F.; Matere, A.; Battaglia, V. Using plant oils to control Fusarium wilt in tomato plants. J. Plant Pathol. 144, 487-495 (2016).

44) Viacava, G.E.; Ayala-Zavala, J.F.; Gonzalez-Aguilar, G.A.; Ansorena, M.R. Effect of free and microencapsulated thyme essential oil on quality attributes of minimally processed lettuce. Postharvest Biol. Technol. 145, 125-133 (2018).

45) Nunan, K.J.; Sims, I.M.; Bacic, A.; Robinson, S.P.; Fincherm, G.B. Changes in cell wall composition during ripening of grape berries. Plant Physiol. 118, 783-792 (1998).

46) Morillon, V.; Debeaufore, F.; Blond, G.; Capelle, M.; Voilley, A. Factors affecting the moisture permeability 
of lipid-based edible films: a review. Rev. Food Sci. Nutri. 42, 67-89(2002).

47) Guerreiro, A.C.; Gago, C.M.L.; Faleiro, M.L.; Miguel, M.G.C.; Antunes, M.D.C. The effect of alginate-based edible coating enriched with essential oils constituents on Arbutus unedo L. fresh fruit storage. Postharvest Biol. Technol. 100, 226-233(2015).

48) Kovace, E.; Hertog, M.; Roth, E.; Vanstreels, E.; Nicolai, B. Relationship between physical and biochemical parameters in apple softening. Paper presented at the V International. Postharvest Symposium 573-578 (2004).

49) Shen, Y.; Yang, H.; Chen, J.; Liu, D.; Ye, X. Effect of waxing and wrapping on phenolic content and antioxidant activity of citrus during storage. J. Food Process. Preserv. 37, 222-231 (2013).

50) Tzortzakis, N.G. Ethanol, vinegar and Origanum vulgare oil vapour suppress the development of anthracnose rot in tomato fruit. International. J. Food Microbiol. 142, 14-18(2010).

51) Amorati, R.; Foti, C.M.; Luca Valgimigli, L. Antioxidant activity essential oils. J. Agric. Food Chem. 61, 10835-10847 (2013).

52) Kelebek, H.; Selli, S.; Canbas, A.; Cabaroglu, T. HPLC determination of organic acids, sugars, phenolic compositions and antioxidant capacity of orange juice and orange wine made from a Turkish cv. Kozan. J. Micro- chemical. 91, 187-192 (2009).

53) Gol, N.B.; Patel, P.R.; Rao, T.V.R. Improvement of quality and shelf-life of strawberries with edible coating enriched with chitosan. Postharvest Biol. Technol. 85, 185-195 (2013).

54) Xie, S.; Lu, T.; Li, B.; Chong, Z.; Lin, S. Relationship between plant phenylalanine (PAL) and peroxidase (POD) activities with the resistance of sweet potato to Ralstonia solanacearum. J. Agric. Sci. 18, 236-238 (2003).

55) Hu, M.; Yang, D.; Huber, D.J.; Jiang, Y.; Li, M.; Gao, Z.; Zhang, Z. Reduction of postharvest anthracnose and enhancement of disease resistance in ripening mango fruit by nitric oxide treatment. Postharvest Biol. Technol. 97, 115-122 (2014).

56) Yingsanga, P.; Srilaong, V.; Kanlayanarat, S.; Noichinda, S.; Meglasson, W.B. Relationship between browning and related enzymes (PAL, PPO, and POD) in rambutan fruit (Nephelium lappaceum Linn.) cvs. Rongrien and See-Chompoo. Postharvest Biol. Technol. 50, 164-168 (2008).

57) Sangsuwan, J.; Pongsapakworawat, T.; Bangmo, P.; Sutthasupa, S. Effect of chitosan beads incorporated with lavender or red thyme essential oils in inhibiting Botrytis cinerea and their application in strawberry packaging system. LWT-Food Sci. Technol. 74, 14-20 (2016). 